\title{
The Impact of Financial Crises on the Informal Economy: The Turkish Case
}

\author{
By Neslihan Kahyalar ${ }^{*}$ Bazoumana Ouattara ${ }^{\dagger} \&$ Sami Fethi ${ }^{*}$
}

Turkey has a large informal economy and has been hit by severe financial crises causing a devastating impact on its economy. The main objective of this paper is to analyse the impact of financial crises on the informal economy in Turkey. We distinguish between four types of financial crises that make up or aggregate financial crises: internal, external, currency and banking crises. Using vector autoregression (VARX) in the presence of two key variables (the financial crisis and the informal economy), we conduct annual time series analysis from 1980 to 2011 and estimate the response of the informal economy to each type of crisis. To our knowledge, this is the first empirical study to examine the effects of financial crises on the informal economy in the context of the Turkish economy. The results show that each type of crisis produces a significantly positive response to the informal economy. In particular, the findings of this paper show that financial crises tend to have a permanent positive effect on the informal economy, suggesting that the informal economy is an important buffer, which tends to expand in times of crises in Turkey. (JEL E26, G01)

Keywords: Informal Economy, Financial Crises, Turkey, Currency Crisis, Banking Crisis, Development.

\section{Introduction}

Financial crises hurt economies around the world, either directly or indirectly, through various transmission channels. Even though effects vary across countries, financial crises have a negative impact on the economy, resulting in sharp declines in growth and employment. The global financial crisis (GFC) of 2007, which has been considered the worst since the Great Depression of the 1930s affected countries with strong as well as weak economies. The emergence of GFC and its painful effects has increased the interest of economists and policymakers to understand the financial crisis and its effects. Much of the current literature on financial crises has paid attention to the effects on the official economy (see, for example, Cerra and Saxena 2008, Laeven and Valencia 2010, Qerimi and Sergi 2017). However, very little is known about the effects on the informal economy (e.g. Colombo et al. 2016). The effect of financial crises on the informal economy has so far remained under-examined. One of the reasons for the absence of studies on this issue might be because of the complexity of both subjects. It is important to note that the informal economy is not easily tractable.

\footnotetext{
*Lecturer in Economics, De Montfort University, UK.

${ }^{\dagger}$ Senior Lecturer in Development Economics, University of Manchester, UK.

"Professor of Economics, Eastern Mediterranean University, Cyprus.
} 
Turkey has been hit harder by financial crises and has fallen into a significant recession since the 1980s. Despite the higher awareness of the informal economy, the informal economy is still a non-tackled issue in Turkey. There has been no fruitful attention given to understanding the impact of financial crises on the informal economy. Therefore, measuring the impact of financial crises on the informal economy represents an important aspect of economic analysis to understand the functions of the Turkish economy. Furthermore, it is worth examining the impact for policy reasons. Given that the informal economy is tremendous in developing countries, the importance of understanding the impact of financial crises cannot be underestimated. The aim of this paper is not to estimate the impact of financial crises on the official economy of Turkey. Rather, the main objective is to analyse the impact of financial crises on the informal economy applying VARX model. This paper seeks to address this gap in the existing literature. This makes it possible to then suggest some tentative propositions about the possible impact of the informal economy on growth and draw a clear conclusion about the informal and official economy's relationship in Turkey.

The rest of the paper is structured as follows: the next section reviews the relevant literature. Section 3 introduces data and methodology. The results and their interpretations are presented in section 4 and the last section concludes.

\section{Literature Review}

A considerable amount of literature has been published on financial crises and their impacts on the official economy (e.g. Demirguc-Kunt et al. 2000, Barro 2001, Hutchison and Noy 2002, Hutchison and Noy 2005, Gupta et al. 2007, Dell' Arricia et al. 2008, Cerra and Saxena 2008, Knotek and Terry 2009, Reinhart and Rogoff 2009, Kroeger and Meier 2011, Furceri and Zdzienneicka 2011, Choudray et al. 2012, Babecky et al. 2012, Fukuda 2012, Verdugo et al. 2012, Qerimi and Sergi 2017). Reinhart and Rogoff (2009) argued three important characteristics of financial crises: a deep collapse in the asset market, a large decline in output and employment, as well as a drastic increase in government debt. In this respect, the authors examined five important developed economy crises and a number of emerging market economies crises. These are 1977 Spain, 1987 Norway, 1991 Finland and Sweden, 1992 Japan, 1997 Asian, 1998 Colombia and 2001 Argentina crises.

They show that financial crises are associated with the economic downturn and a large decline in output. Regressing 5-year average output growth on several control variables such as openness, per capita GDP for the period of 1965 and 2000, Barro (2001) showed the currency crisis is associated with a $1.3 \%$ decrease in average output growth but banking crisis is found to be $0.6 \%$ decrease in average output growth. Output effects of currency crises are analysed by Hutchison and Noy (2002) using the panel data set for the period 1975-1997 in 24 emerging market economies. They show that currency crises are associated with significant declines in output by about 5-8\% over a 2-year period. By contrast, Demirguc- 
Kunt et al. (2000) focussed on the output costs associated with banking crises. They perform a cross-section of 36 banking crises and found that banking crises are associated with large declines in output growth of about $4 \%$. Focusing on the twin crises phenomenon, Hutchison and Noy (2005) investigated output effects of both banking and currency crises and their joint effects on the real economies of 24 emerging countries, including Argentina, Brazil, Turkey, Thailand, South Africa and Mexico. They found that each type of crisis severely damaged the economy. However, banking crises are found to be costlier, normally with $8 \%$ $10 \%$ decline in output growth over 2-4-year periods, followed by currency crises with 5\%-8\% declines in output growth for the same period. They showed that the cumulative loss of both crises is very large, $13 \%-18 \%$ of output. Gupta et al. (2007) examined the behaviour of output in times of currency crises in 91 developing countries (17 Asian, 42 African, 20 Latin American and 12 Central and Eastern European and Middle East countries). The results show almost $60 \%$ of currency crises have a contractionary effect on output. Using two different methodologies, the vector error correction model (VECM) and the autoregressive distributed lag (ARDL) techniques, Fukuda (2012) examined the relationship between financial crises and economic growth in Indonesia, Korea, Malaysia, Thailand and India and show that financial crises have had a negative impact in all these countries. In the same way, using ARDL technique, Furceri and Zdzienneicka (2011) looked at and compared the impact of financial crises on output in eleven transition countries (CEECs) and advanced European economies (EU-15). They found that crises have a significant negative impact on output by lowering it $17 \%$ in CEECs. Unlike CEECs, financial crises lower output by $2 \%$ in EU-15. On an impact of output loss of financial crises in developed countries, Babecky et al. (2012) is probably the best-known study on the financial crisis in the context of developed countries. They examined the effect of several types of crisis including currency crisis, banking crisis and debt crisis on economic activities in terms of output loss for a panel of 40 developed countries from 1970 to 2010 . The mean cumulative loss is about $25 \%, 15 \%$ and $4 \%$ following the banking, currency and debt crises respectively.

Kroeger and Meier (2011) examined the labour market impact of GFC in a transition country, Tajikistan. Applying multinomial probit regression from 2007 and 2009, they found an increased probability of being unemployed, inactive and involved in unpaid works in times of crises. Applying vector autoregression (VAR) model, Verdugo et al. (2012) also measured the impact financial crises on unemployment using a panel of 97 countries from 1980 to 2008 and found a significant and long-lasting increase in the unemployment rate after the financial crisis. Focusing on youth unemployment rate in a large panel of countries (70) for the 1980-2005, Choudray et al. (2012) analysed the impact of financial crises on the youth unemployment rate and show that financial crises cause a substantial increase in youth unemployment. Knotek and Terry (2009) examined the relationship between the banking crisis and unemployment from 1960 to 2007 in 33 high-income countries. Based on the vector autoregression analysis (VAR), they find that the unemployment rate increased by almost 2.5 percentage points over the four years. In addition, if banking crises coincide with the recession, the 
impact on unemployment is even found to be worse which increases 3.5 percentage points over the four years. The recent paper by Qerimi and Sergi (2017) looked at the impact of GFC and eurozone crises on employment in South East Europe. The authors suggest both GFC and eurozone crises significantly contributed to the high level of unemployment in the area.

Focusing on the impact of financial crises on the informal economy, theoretical and empirical research is not extensive. In their studies, Roca et al. (2001) and Elgin (2012) emphasised the role of the informal economy as countercyclical in times of crises. Elgin (2012) investigated the relationship between the business cycle and the size of the informal economy in 152 countries using panel regression and show that the size of the informal economy tends to decrease in booms but increase in busts. Schneider and Buehn (2012) estimated the size of the informal economy in highly developed 39 OECD countries from 1999 to 2010. The authors' calculation shows an increase in the size of the informal economy and they argue that the increase in the size is caused by the GFC. There are only two main studies that directly focus on the impact of financial crises on the informal economy. Colombo et al., (2012) employed total electricity approach for a panel of 120 countries from 1980 to 2005 using an autoregressive model. The results show that financial crises have a strong negative impact on official output. By contrast, they found a positive response of the informal economy to financial crises. The effect of the banking crisis is found to be much stronger than the currency crisis on the informal economy. Like their earlier study, Colombo et al. (2016) investigated the effect of the banking crises on the informal economy. Using a dynamic stochastic general equilibrium model, they found the positive response of the informal economy to banking crises.

Turkey is a growing and dynamic free market economy. In Turkey, the growth rate has been erratic, and the country has been struggling with employment problems. As indicated by Nathason and Brand (2011), Turkey has the potential to be one of the largest economies in Europe, but economic growth has been subject to many obstacles. Inefficient macroeconomic policies, legal, structural and political disorders have led Turkey to be hit harder by currency, banking, debt, twin crises both domestic and global. For example, between 1997 and 1999, both Asian and Russian crises and two disastrous earthquakes, were devastating, the effect of these crises were immediately felt in the Turkish economy. Similarly, 2000-2001 currency and banking crises crippled the Turkish economy. Regarding the 2000-2001 crises, Temiz and Gokmen (2009) argued that Turkey experienced a huge decrease in capital flows, a substantial increase in interest rates, sharp depreciation of Turkish lira by $50 \%$ and a sharp increase in unemployment. In the same vein, Ozturk and Aras (2011) claimed that 2000-2001 crises were destructive, and the Turkish economy contracted by $9.4 \%$ with a dramatic increase in inflation (70\%). Considering Global financial crises (GFC) started as US property market crash and rapidly spread across countries, Aras (2010) argued that Turkey was negatively affected by the GFC by experiencing large contractions in terms of GDP. The informal economy is one of the major characteristics of the Turkish economy. Several studies have documented its persistence and pervasiveness (e.g. Ercan 2011, Eurofound 2013, Schneider et al. 2010, Simsek 
2014, World Bank 2010). The informal economy is part of many people's daily routine. The International Labour Organization ILO (2012) reported that informality among young people in Turkey is significant (58.8\%) compared with adults $(43.8 \%)$. The report states that it is because the official economy is unable to create sufficient formal employment opportunities. Simsek (2014), a Former Deputy Prime Minister, claimed the informal economy is a key issue to tackle in Turkey because it slows the economic growth, production, cause significant loss of tax revenue and creates wage inequality. It is also important to note that Turkey has a higher degree of informality in comparison with European counties. For instance, the size of the informal economy is larger in Turkey than in the EU-27 countries (Buehn and Schneider 2012). The evidence presented suggests that the informal economy and financial crises play a very important role in Turkey's economy and has important economic and social functions.

\section{Data and Methodology}

Data

The data used in the estimation process covers the period between 1980-2011 and were collected from three main sources: (i) Real GDP and terms of trade (TOT) data are obtained from World Bank Development Indicators (WDI). TOT is defined as the ratio of price deflator for imports and the price deflator for exports. (ii) The data on the informal economy was obtained from the authors' estimation of the size of the informal economy. The dependent variable is the size of the informal economy. This is estimated using the MIMIC (Multiple Indicators and Multiple Causes) approach and the electricity consumption method for each model. $^{1}$ (iii) The financial crises dates are taken from Reinhart and Rogoff database (RR). ${ }^{2}$ RR database consists of crisis dates (onset of a crisis) covering a wide range of counties (70 countries). Each crisis is measured by a dummy variable, which takes the value 1 when the country is considered to be in a corresponding crisis and 0 when no crisis occurred. The analysis is based on the data from 1980 onwards and covers currency crises, banking crises and sovereign debt crises.

As this paper's primary aim is to measure the aggregate impact of financial crises on the informal economy, a new variable called "financial crises" is created. The variable is compiled from RR database banking crises, currency crises and sovereign debt crises. It does not distinguish between internal and external crises and it represents a situation whereby a country experiences either a specific type of crisis or twin or triple crises. The financial crises variable is measured by a dummy

\footnotetext{
${ }^{1}$ We also estimate the size of the informal economy based on electricity consumption method. This second source is used as the dependent variable for robustness check. Results of each method of measurement are available upon request.

${ }^{2}$ Appendix Table A1 provides a summary of the definition of crises by http://www.reinhartand rogoff.com/. For more information on financial crises, dates and definition see also Reinhart (2010) and Reinhart and Rogoff (2011).
} 
variable and takes value 1 when the country is judged to experience corresponding crises and 0 when no crisis occurred. Second, compiling the data from the RR database, we distinguish between internal and external crises and examine the effects of internal and external crises on the informal economy separately. The variable "internal crises" consists of a currency crisis, banking crisis, debt crisis or twin crises that occurred domestically and the variable "external crises" consist of crises either currency crisis, banking crisis, debt crisis or twin crises that are foreign in origin. Both internal and external crises are also measured by dummy variables and take on value 1 in times of crises and 0 in other periods. Third, having considered that Turkey has faced many currencies and banking crises, the effect of currency and banking crises are examined. For this analysis, banking and currency crises dates are obtained from the RR database. As before, both crises are expressed as a dummy variable equal to 1 when a country is in crisis and 0 otherwise. As a result, Turkey has experienced 25 financial crises at the aggregate level. 23 currency crises, 7 banking crises, 2 external debt crises, 1 internal debt crisis, 20 internal crises including currency, banking and domestic debt crises, and 7 external crises including currency, banking, twin and external debt crises over the past 30 years. It is important to emphasise that the use of dummy variables in the VARX is not a new application. See, for example, Fomby et al. (2013) in Journal of Applied Econometrics, who use dummy variables for disaster-related events to examine the effects of natural disasters on growth.

\section{Econometric Methodology}

The econometric analysis is based on the vector autoregression model in the presence of both endogenous and exogenous variables (VARX) proposed by Pesaran et al. (2000) and Pesaran and Pesaran (2009). This model allows for the study of the dynamics of each type of financial crises and their effects on the informal economy. Following Pesaran and Pesaran (2009), given a set of $\mathrm{m}$ endogenous and $n$ exogenous variables, the general framework of the VARX model can be described in the following form:

$\Delta y_{t}=a_{0}+a_{1 y} t-\Pi_{y} z_{t-1}+\sum_{i=1}^{p-1} \Gamma_{i y} \Delta \mathrm{z}_{t-i}+\Psi_{y} w_{t}+\varepsilon_{t}$

Where, $z_{t}=\left(y_{t}^{\prime} x_{t}^{\prime}\right)^{\prime}, y_{t}$ is a vector of endogenous variables, $x_{t}$ is a vector of exogenous variables. $a_{0}$ and $a_{1 y}$ represent the intercept and the trend coefficients respectively. $w_{t}$ is vector of exogenous $\mathrm{I}(0)$ or deterministic variables. $\Pi_{y}$ is the matrices of long-run coefficients and $\Gamma_{i y}$ is the matrices of short run coefficients. $\Psi_{y}$ denotes the coefficient matrix of $\mathrm{I}(0)$ exogenous or deterministic variables. $\Pi$ stands for a cointegrating relationship and has a deficient rank, $r$, which represent a number of cointegrating vectors. If $\Pi$ is equal to zero $(\Pi=0)$, this implies that 
there is no cointegration. However, if $\Pi$ is not equal to zero $(\Pi \neq 0)$, this implies that there is a cointegrating relationship. When there is an $r$ cointegrating relationship, $\Pi$ can be expressed as below:

$\Pi=\alpha \beta^{\prime}$

Where $\alpha$ and $\beta$ are $m \times r$ full rank matrices. $\alpha$ is an error correction coefficient and $\beta$ corresponds to cointegrating coefficients. Localisation of intercept and trends are important in cointegration analysis. In empirical work, since it is difficult to know whether there are linear trends in variables or whether they cancel themselves in cointegration relations, Pesaran et al. $(1997 ; 2000)$ differentiate five different cases. Case I (no intercept and no trends, $a_{0}=a_{1}=0$ ),

Case II (restricted intercept and no trend, $a_{1}=0$ and $a_{0}=\Pi_{y} \mu_{y}$ ), Case III (unrestricted intercept and no trend, $a_{1}=0$ and $a_{0} \neq 0$ ), Case IV (unrestricted intercept and restricted trend, $a_{0} \neq 0$ and $a_{1}=\Pi_{y} \gamma_{y}$ ) and Case $\mathrm{V}$ (unrestricted intercept and trend, $a_{0} \neq 0$ and $a_{1} \neq 0$ ). It should be noted that Pesaran et al. (2000) argue that Case II is likely to be particularly relevant in practice and preferable to the corresponding unrestricted cases. Therefore, Case II was adopted for this study.

\section{Model Specification}

Equation (1) is the cointegration VARX model we adopted in our estimation. This econometric approach above is applied to three different models. The first (Model I) considers the financial crisis at an aggregate level including currency, banking, debt, the classic "twin" crises, internal and external crises, and attempts to test the overall impacts of financial crises on the informal economy. In this model, $y_{t}$ denotes a vector of endogenous variables containing real GDP and the

informal economy. TOT is included in the model as an $\mathrm{I}(0)$ exogenous variable, which allows a determination of how global factors affect domestic economic growth and other endogenous variables (Fomby et al. 2013). Financial crisis is the dummy variable (deterministic variable).

In the second model (Model II), the distinction is made between the effects of internal (domestic) and external (global) crises in order to carry out an empirical analysis of the sensitivity of the informal economy to each type of crisis separately. To set up the VARX model, as before, two endogenous variables (real GDP and the informal economy) are included in the model and terms of trade is considered as exogenous I $(0)$ variable. Internal and external dummies are dummy variables we wish to include to investigate their impacts on the informal economy. Dummy variables are included in the VARX as deterministic variables. The RR database shows that Turkey has been mainly hit by currency (23) and banking (7) 
crises since the 1980s. Thus, we finally consider the currency and banking crises and attempts to identify the effect of these crises on the informal economy. We specify, therefore, the model (Model III) including currency and banking crises. This model contains the following variables: the informal economy and the real GDP as endogenous variables and terms of trade as an exogenous $\mathrm{I}(0)$ variable. Again, currency and banking crises dummies are included in the model as deterministic variables.

The estimation results are conducted by Microfit 5, which allows separating between the endogenous, exogenous and deterministic variables. The set of endogenous variables are followed by an exogenous variable (TOT) which is then followed by deterministic variables (dummies). ${ }^{3}$ Prior to the implementation of our cointegrated VARX model, we check the stationarity of variables. In order to check whether variables are stationary, three unit root tests are used: Augmented Dickey-Fuller (ADF), Phillips-Perron (PP) and Dickey-Fuller Generalised Least Squared (DF-GLS) tests. Unit root test results are summarised in Table 1. As shown all three tests at level indicate that the informal economy (IE) (IE using the MIMIC model approach and IE2 using the electricity consumption method) and the real GDP are not stationary. The unit root tests of TOT variable shows the presence of stationary in level $\mathrm{I}(0)$. The null hypothesis of a unit root for TOT variable is rejected at $1 \%$ significance level.

Table 1. Unit Root Tests

\begin{tabular}{|l|c|c|c|c|c|c|c|}
\hline & \multicolumn{2}{|c|}{ ADF test } & \multicolumn{2}{c|}{ PP test } & \multicolumn{2}{c|}{ DF-GLS test } & \\
\hline Var. & $\begin{array}{c}\text { In } \\
\text { Level }\end{array}$ & $\begin{array}{c}\text { In } \\
\text { diff. }\end{array}$ & $\begin{array}{c}\text { In } \\
\text { Level }\end{array}$ & $\begin{array}{c}\text { In } \\
\text { diff. }\end{array}$ & $\begin{array}{c}\text { In } \\
\text { Level }\end{array}$ & $\begin{array}{c}\text { In } \\
\text { diff. }\end{array}$ & Con. \\
\hline GDP & -2.924 & $-5.834^{* * *}$ & -2.958 & $-6.803^{* * *}$ & -2.892 & $-6.013^{* * *}$ & $\mathrm{I}(1)$ \\
\hline IE & -2.736 & $-5.590^{* * *}$ & -2.803 & $-6.378^{* * *}$ & -2.756 & $-5.740^{* * *}$ & $\mathrm{I}(1)$ \\
\hline IE2 & -1.677 & $-6.077^{* * *}$ & -1.636 & $-6.847^{* * *}$ & -1.939 & $-6.220^{* * * *}$ & $\mathrm{I}(1)$ \\
\hline TOT & $-5.440^{* * *}$ & - & $-5.548^{* * *}$ & - & $-3.795^{* * *}$ & - & $\mathrm{I}(0)$ \\
\hline
\end{tabular}

Source: Author.

Note: (a) all test takes unit root as null hypotheses and asterisk ${ }^{* * *}$ denotes rejection of the null hypothesis at $1 \%$ significance level, (b) all test are done with the trend and intercept, (c) for ADF test, Akaike information criterion is used to select the lag length and the maximum lag length is set to be 2. For the PP test, Newey-West is used to select a bandwidth.

It is also important to determine the lag structure of the VARX model before proceeding to the estimation of models. Given that we have annual data we set the maximum lag number to 2 and use two well-known criteria, Akaike Information Criterion (AIC) and Schwarz Bayesian Information Criterion (SBC) to determine the appropriate lag order. Both information criteria suggest one lag for each model. $^{4}$

${ }^{3}$ For further information, see Pesaran and Pesaran (2009). For each model, endogenous variables are followed by exogenous and deterministic dummy variables.

${ }^{4}$ All tests are obtained using Microfit 5.0. For further technical details see Pesaran and Pesaran (2009). 
Table 2. Cointegration Test Statistics for Models

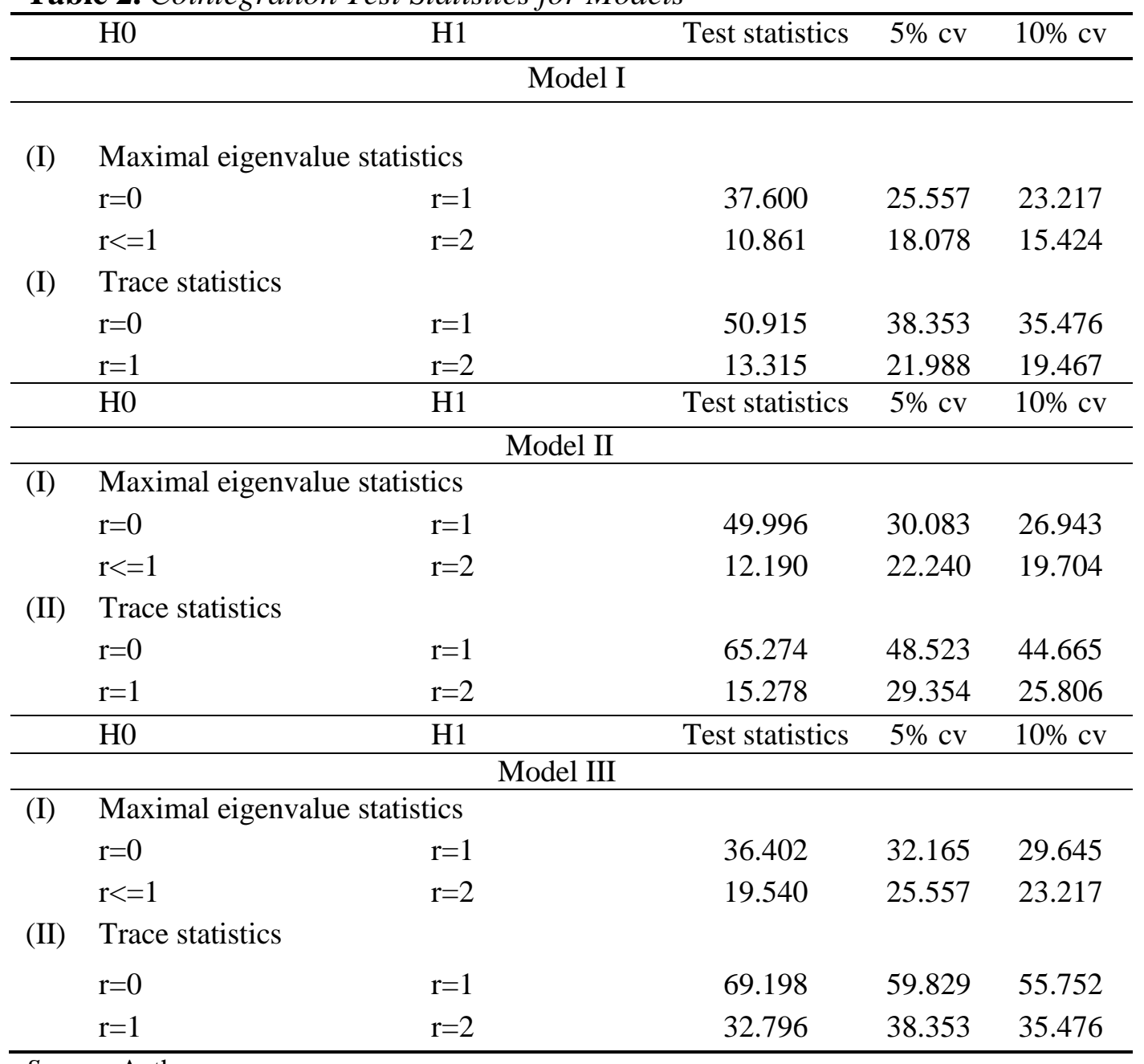

Source: Author.

After determining the appropriate lag order, cointegration test is performed. Since Johansen cointegration method involves estimation of more than one equation, allows the possibility of more than one cointegrating relations and has an advantage in the case of small samples, in order to test cointegration, the Johansen method is used in this study. ${ }^{5}$ It should be noted that TOT is included as an unrestricted deterministic $\mathrm{I}(0)$ exogenous variable in each model. Thus, cointegration is tested only on non-stationary variables. ${ }^{6}$ The test statistics are computed using 30 observations from 1980 to 2011 . The 5\% and 10\% critical values are computed by stochastic simulations using 1000 replications. The cointegration test results for Model I, Model II and Model III are summarised in Table 2 . The cointegration test clearly rejects the null position of no cointegration at the $5 \%$ level when using the maximum eigenvalue test. Similar results are obtained when using the trace test. Similar to Model I, the maximum eigenvalue

${ }^{5}$ For further discussion of Johansen cointegration test and its advantages, see Johansen (1988; 1991).

${ }^{6}$ See Pesaran and Pesaran (2009) for technical details. 
and trace statistics demonstrate that there exists one cointegrating relation. For Model III, the maximum eigenvalue test rejects the null hypothesis $r=0$ against $r=1$ at the 5\% level. Turning to the trace test, this gives equivalent results. Overall, it appears that both maximum eigenvalue and trace tests suggest the presence of one cointegration relation at the 5\% level for baseline models. The test results are supportive of the existence of one long-run relationship, which is between the informal economy and the real GDP.

\section{Results}

\section{Impulse Responses for Baseline Models}

To investigate the effects of financial crises, the mean responses are used. Mean responses trace the effect of shocks on current and future values of each variable in the VARX system and provide useful information on the persistence of shocks for a long-time horizon. Analysis of impulse responses also enables researchers to investigate the dynamic relationship of variables over time (Pesaran and Pesaran 2009). Given the model specification, each VARX model is used to simulate the effects of financial crises on the selected variables in the system, which provides a meaningful interpretation of the initial impact of the financial crisis shocks. ${ }^{7}$ The following figures and tables show the mean responses of the informal economy to each type of financial crisis for the first 10 years between 1980 and 2011 (year 0 denotes the year that financial crises occurred). Since the objective of this paper is to trace the dynamic path of adjustment in the aftermath of crises, the mean response of the informal economy to a given crisis is the most relevant analysis. The significance of results, evaluated by $90 \%, 95 \%$ and $99 \%$ confidence intervals derived from Monte Carlo simulations, are presented in Tables 3 to 5, for the informal economy. In addition, mean responses of the informal economy for each financial crisis are illustrated by graphs at $95 \%$ confidence interval $(\mathrm{CI})$ that give a visual representation of responses (Figures 1$3)$. In each graph, points above zero show positive responses and points below zero show negative responses.

\section{The Impact of an Aggregate Financial Crisis on the Informal Economy (Model I)}

The mean responses of the informal economy to a financial crisis and graphical representations of the mean responses corresponding to a confidence interval of $95 \%$ are shown in Table 3 and Figure 1 respectively. The results show that the mean response of the informal economy to financial crises is significantly positive and very strong in terms of statistical significance, except for year 0 . The mean response of the informal economy to the financial crisis is positive in the year of the event, but it is not significant. The effect becomes significant in the first year at a $1 \%$ level, and, as illustrated in Figure 1, it increases gradually following the financial crises, and tends to be highly significant after the crisis. The response

${ }^{7}$ For further discussion see Pesaran and Shin (1998) and Lee and Pesaran (1999). 
of the informal economy increases from $4 \%$ (first-year impact) to $5.6 \%$ and $6.7 \%$ in the second and third years respectively, and in subsequent years, it continues to increase slightly. Estimated results clearly indicate that there is no sign of drop-in responses of the informal economy, but a build-up of positive responses for the long-term horizon. These results, in turn, suggest that financial crises have a longlasting positive effect on the informal economy.

Table 3. Mean Response of the Informal Economy to Financial Crises

\begin{tabular}{lc}
\hline Years & Financial crises \\
\hline Year 0 (instantaneous response) & 0.009 \\
Year 1 & $0.039^{* * *}$ \\
Year 2 & $0.056^{* * *}$ \\
Year 3 & $0.067^{* * *}$ \\
Year 4 & $0.073^{* * *}$ \\
Year 5 & $0.077^{* * *}$ \\
Year 6 & $0.080^{* * *}$ \\
Year 7 & $0.081^{* * *}$ \\
Year 8 & $0.082^{* * *}$ \\
Year 9 & $0.083^{* * *}$ \\
Year 10 & $0.084^{* * *}$ \\
\hline
\end{tabular}

Source: Author.

Notes: (a) ${ }^{* * *}$ indicates $1 \%$ significance level; (b) 1000 replications were used in bootstrap confidence interval of impulse responses.

One explanation could be that financial crises are followed by deep economic contractions due to large declines in demand. Therefore, the positive response of the informal economy could be explained by an economic downturn due to decreases in real GDP. Consistent with the existing literature (e.g. Aras 2010, Yendi et al. 2012), financial crises are found to be harmful to real GDP. The results show that the mean response of the real GDP to financial crises is deeply negative on the year of the event, and no significant recovery occurs in the following years (see Figure A1, Graph (a) in Appendix). Hence, these findings support the notion that financial crises tend to disrupt economic activities, causing unemployment to rise, seeing decreases in family income and forcing people to look for extra income. Furthermore, declines in GDP may also negatively impact the government's ability to create official jobs, due to deterioration within institutional and financial settings. It is worth noting that in the case of Turkey, demographic pressures may also aggravate the situation. The Turkish population and the working age population grow very fast. Hence, the Turkish labour force is growing. However, job creation in the formal economy has a limited ability to accommodate the growing labour force (Ercan, 2011). This, in turn, may induce people to look for jobs in the informal economy. 
Figure 1. Mean Response of the Informal Economy to Financial Crises

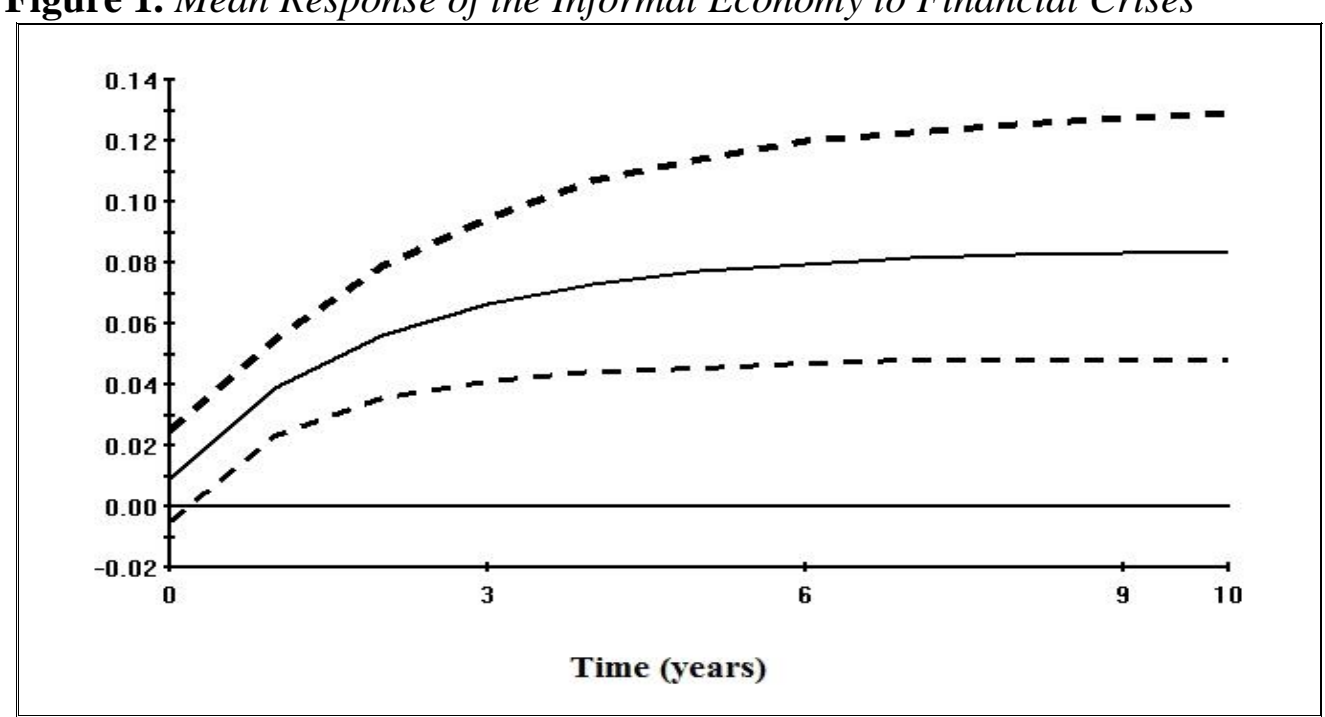

Source: Author.

Note: the solid line represents the estimated IRFs and dotted lines represent $95 \%$ confidence interval.

The Impact of Internal and External Crises on the Informal Economy (Model II)

In order to investigate the effects of internal and external crises separately, the financial crises are disaggregated into internal and external ones. The results of the mean responses are reported in Table 4 and illustrated in Figure 2. As column (a) of the Table and Figure 2 graphs (a) show, the mean responses of the informal economy to internal crises is positive and significant on the year of the event at a $5 \%$ level. Internal crises produce a highly significant response to the informal economy in year 1 and in subsequent years. Specifically, the response of the informal economy increases by $3.5 \%$ in the $1^{\text {st }}$ year to $5.6 \%$ in the $5^{\text {th }}$ year and to $5.9 \%$ in the $10^{\text {th }}$ year indicating its permanent positive effect on the informal economy. Similar to aggregate financial crises, there is no sign of a drop in the response of the informal economy, but a build-up of positive responses over the years. However, it should be noted that the mean response of the informal economy tends to stabilise 6 years later in years 7 and 8 after the crises at around $5.8 \%$. Then a slight increase was observed in the response of the informal economy 1 year later in year 9 at 5.9\%, though the effect remains positive and significant, but does not tend to increase thereafter. 
Table 4. Mean Response of the Informal Economy to External and Internal Crises

\begin{tabular}{|l|c|c|}
\hline Years & Internal crises (a) & External crises (b) \\
\hline Year 0 (instantaneous response) & $0.012^{* * *}$ & 0.003 \\
\hline Year 1 & $0.035^{* * *}$ & $0.028^{* * *}$ \\
\hline Year 2 & $0.045^{* * *}$ & $0.037^{* * *}$ \\
\hline Year 3 & $0.051^{* * *}$ & $0.044^{* * *}$ \\
\hline Year 4 & $0.054^{* * *}$ & $0.047^{* * *}$ \\
\hline Year 5 & $0.056^{* * *}$ & $0.049^{* * *}$ \\
\hline Year 6 & $0.057^{* * *}$ & $0.050^{* * *}$ \\
\hline Year 7 & $0.058^{* * *}$ & $0.051^{* * *}$ \\
\hline Year 8 & $0.058^{* * *}$ & $0.052^{* * *}$ \\
\hline Year 9 & $0.059^{* * *}$ & $0.052^{* * *}$ \\
\hline Year 10 & $0.059^{* * *}$ & $0.052^{* * *}$ \\
\hline
\end{tabular}

Source: Author.

Notes: (a) ${ }^{* *}$ and ${ }^{* * *}$ indicate $5 \%$ and $1 \%$ significance level of financial crisis shocks respectively; (b) 1000 replications were used in the bootstrap confidence interval of impulse responses.

Estimated results show that internal crises are inversely related to real GDP. The negative impact is also felt in the year of the internal crises. In subsequent years, the real GDP does not recover, which in turn may explain the increase in the response of the informal economy (see Figure A1, Graph (b) in Appendix). It might be argued that internal crises cause economic, social, financial and institutional insufficiency. Thus, the inadequacy of government and financial institutions leads to a shrinking pool of jobs available in the official economy and triggers the unemployment problem of Turkey. On the supply side, a person who cannot afford to be unemployed and looks for extra income accepts the jobs available in the informal economy. On the demand side, the financial crisis may also force employers to go underground and employ workers informally. Hence, these results suggest positive impacts on the informal economy as it serves as a cushion in times of crises. Furthermore, these results are also in line with the existing literature. For example, Ercan (2011) reports that informal employment rose by 2.3 points during the 2001 crisis and remained high in the following two years due to official job losses in Turkey. Given the country's high population growth, rapid internal migration and chronic unemployment, the positive effects of internal crises on the informal economy are not surprising.

Turning now to the response of the informal economy to external financial crises as shown in column (b) of Table 4 and the Figure 2, graph (b) there is no significant response in the year of the external crisis, unlike internal crises. The results show that the informal economy is significantly affected by an external crisis, but with some delay: in year 1 after the crisis, a significant increase in the response of the informal economy continues to occur in the following years. The response of the informal economy rises from $2.8 \%$ in the $1^{\text {st }}$ year to $4.9 \%$ in the $5^{\text {th }}$ year and reaches a peak response in the $10^{\text {th }}$ year $(5.2 \%)$. Similar to internal financial crises, results exhibit significant and permanent effects on the informal economy due to external crises but in year 1 after the crises. Recent evidence also 
suggests that external crises can have a considerable influence on the informal economy in Turkey. For example, Yazir (2010) states that with the effect of the global financial crisis (GFC) on the Turkish economy, unemployment increased by $0.7 \%$ in 2008 and $3 \%$ by the end of 2009 , and in turn, unregistered employment gained momentum and increased $0.4 \%$ by the end of 2009, adding 108,000 more people as participants in the informal economy.

Figure 2. Mean Response of the Informal Economy to Internal and External Crises

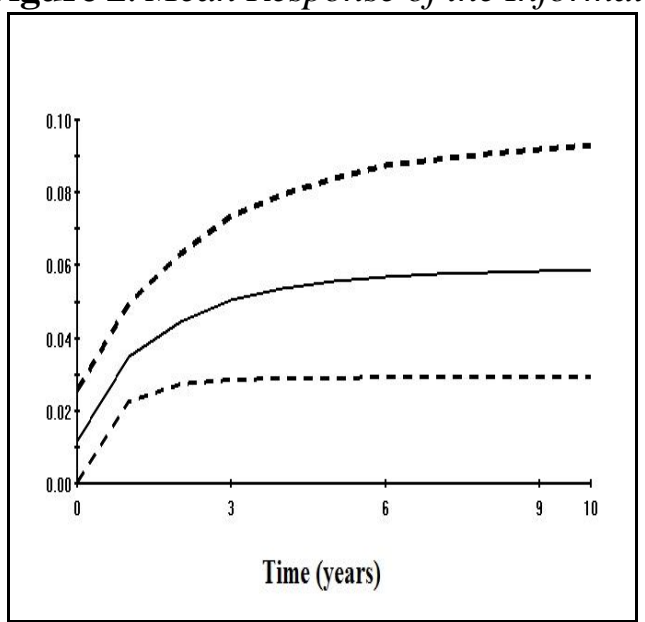

(a)

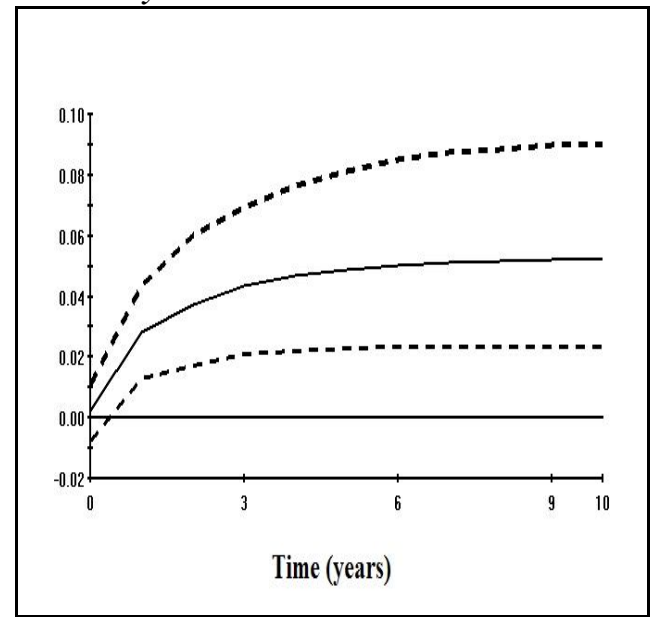

(b)

Source: Author.

Note: the solid line represents the estimated IRF and dotted lines represent $95 \%$ confidence interval.

The Impact of Currency and Banking Crises on the Informal Economy (Model III)

Currency and banking crises' effects are estimated separately to identify their different impacts on the informal economy. Regarding these two crises, the results on the mean response of the informal economy are presented in Table 5 and Figure 3. As reported in column (a) of the Table and portrayed in Figure 3 graph (a), a currency crisis appears to have a negative impact, but not a statistically significant impact on the informal economy in the same year as the crisis itself. A negative initial response within the informal economy can be explained by the fact that a currency crisis lowers the value of a currency and hence the purchasing power of individuals. Since the informal economy is essentially a cash economy, the initial response is negative. However, as explained, this negative effect is not statistically significant. The positive and significant impact of a currency crisis is felt in year 1 . The mean responses in the subsequent years remain positive and statistically significant and gradually increase from year 1 to year 7. Although there is no sign of an increase in the response of the informal economy after 7 years, the impact remains positive and significant on the informal economy with an average of $4 \%$ for the investigated period. 
Table 5. Mean Response of the Informal Economy to Currency and Banking Crises

\begin{tabular}{|l|c|c|}
\hline Years & Currency crisis (a) & Banking crisis (b) \\
\hline Year 0 (instantaneous response) & -0.005 & $0.019^{* *}$ \\
\hline Year 1 & $0.018^{*}$ & $0.035^{* * *}$ \\
\hline Year 2 & $0.029^{* *}$ & $0.043^{* * *}$ \\
\hline Year 3 & $0.034^{* *}$ & $0.047^{* * *}$ \\
\hline Year 4 & $0.037^{* * *}$ & $0.049^{* * *}$ \\
\hline Year 5 & $0.039^{* * *}$ & $0.050^{* * *}$ \\
\hline Year 6 & $0.040^{* * *}$ & $0.051^{* * *}$ \\
\hline Year 7 & $0.040^{* * *}$ & $0.051^{* * *}$ \\
\hline Year 8 & $0.041^{* * *}$ & $0.051^{* * *}$ \\
\hline Year 9 & $0.041^{* * *}$ & $0.051^{* * *}$ \\
\hline Year 10 & $0.041^{* * *}$ & $0.051^{* * *}$ \\
\hline
\end{tabular}

Source: Author.

Notes: (a) ${ }^{* * *}$ and ${ }^{* * *}$ indicate $10 \%, 5 \%$ and $1 \%$ significance level of financial crisis shocks respectively. (b) 1000 replications were used in bootstrap confidence interval of impulse responses.

In contrast to currency crises, as shown in column (b) of Table 5 and Figure 3, graph (b), the positive and significant impacts of a banking crisis are felt in the year of the crisis. The effect remains statistically significant at $1 \%$ level for the following 10 years. Specifically, the mean response of the informal economy to a banking crisis is deeply positive from year 0 to year 10, but there is no increase in the response of the informal economy after 5 years of that crisis. The response of the informal economy remains constant and significant at $5.1 \%$, indicating the presence of long-lasting effects of a banking crisis. In terms of banking crises, the response of the informal economy is found to be around 5\% on average, which is higher than for currency crises.

Turning to the currency crises vs. banking crises, the estimations show the informal economy is more likely to be affected by banking crises than currency crises in Turkey. The mean response of the informal economy to banking crises is stronger in terms of size than currency crises. In fact, banking crises have almost more than twice the positive impact in year 1 and are bigger in size over the next 10 years. The cumulative positive response of the informal economy to banking crises is about $50 \%$, considerably higher than for currency crises $(35.5 \%)$. However, both crises bring about a positive mean response for the informal economy in year 1 and the following years, and their effects are long-lived. Regarding the difference between the effects of currency and banking crises, a recent paper by Oulton and Barriel (2013) indicates that banking crises are fundamentally different from another type of crises, i.e., currency crises. They find that banking crises have more severe and long-lasting effects on growth. In line with Oulton and Barrier (2013), our results also suggest the severity of banking crises from year 0 to 10 on real GDP, which might be closely associated with stronger impacts of banking crises on the informal economy (see Figure A1, Graph (e) in Appendix). In addition, according to Colombo et al. (2012, 2016), different responses to different crises can be explained by examining the role of 
the informal economy. They argue that the effect of currency crises (acting as inflation shocks) on the informal economy is constrained by inflation, which acts as a tax on cash holding and affects the informal economy more than the official economy since the informal economy is more cash intensive. In fact, the effects of banking crises, which are found to be stronger, reinforce this argument.

Figure 3. Mean Response of the Informal Economy to Banking and Currency Crises

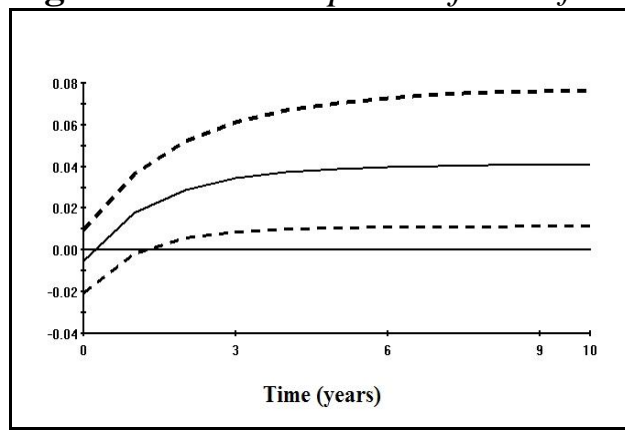

(a)

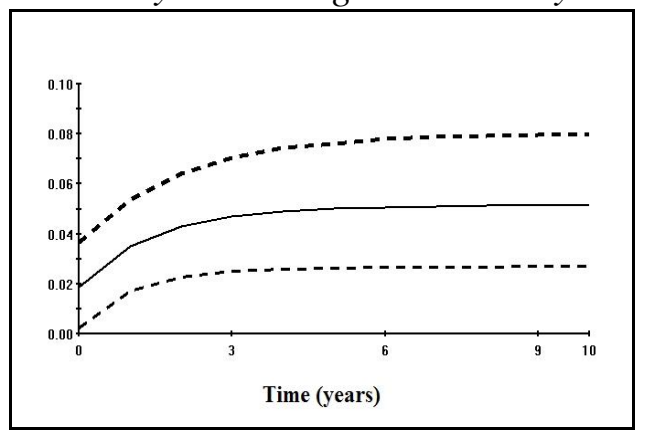

(b)

Source: Author.

Note: the solid line represents the estimated IRF and dotted lines represent a 95\% confidence interval.

\section{Robustness Check}

To check the robustness of results, the econometric approach we adopted, is re-estimated using the alternative measurement of the informal economy. Indeed, the informal economy is estimated using what is called the electricity consumption method. Then, the econometric model (equation 1) is applied to model 1, model II and model III. One of the main advantages of this method is that it does not only consider electricity consumption as an indicator but is also consider electricity production, energy consumption and energy production as indicators.

Prior to estimating results, it is important to determine the lag order of endogenous and exogenous variables. For this purpose, given that the data is annual, the maximum lag is set to 2 and AIC and SBC are used to ascertain the lag order of VARX. Both information criteria suggest a VARX of order 1. Subsequent to this, the null hypothesis of cointegration is tested using Johansen maximum eigenvalue and trace statistics. Cointegration test results are summarised in Table 6 for each model. The results reject the null hypothesis of no cointegration at a 5\% level when using maximum eigenvalue statistics for each model. Similar results are obtained using trace statistics. As in the baseline models, cointegration test indicates the existence of one cointegrating vector, which implies a long-term relationship between the real GDP and the informal economy. 
Table 6. Cointegration Test (Alternative Models of a Financial Crisis)

\begin{tabular}{|c|c|c|c|c|c|}
\hline & $\mathrm{H} 0$ & H1 & Test statistics & $\begin{array}{l}5 \% \\
\mathrm{cv}\end{array}$ & $\begin{array}{c}10 \% \\
\mathrm{cv}\end{array}$ \\
\hline \multicolumn{6}{|c|}{ Model I } \\
\hline \multirow[t]{3}{*}{ (I) } & Maximal eigenvalue statistics & & & & \\
\hline & $\mathrm{r}=0$ & $\mathrm{r}=1$ & 41.091 & 25.557 & 23.217 \\
\hline & $\mathrm{r}<=1$ & $\mathrm{r}=2$ & 8.520 & 18.078 & 15.424 \\
\hline \multirow[t]{3}{*}{ (II) } & Trace statistics & & & & \\
\hline & $r=0$ & $\mathrm{r}=1$ & 53.220 & 28.353 & 35.476 \\
\hline & $\mathrm{r}=1$ & $\mathrm{r}=2$ & 12.130 & 21.988 & 19.467 \\
\hline \multirow[t]{3}{*}{ H0 } & & H1 & Test statistics & $5 \%$ & $10 \%$ \\
\hline & & & & $\mathrm{cv}$ & $\mathrm{cv}$ \\
\hline & \multicolumn{5}{|c|}{ Model II } \\
\hline \multirow[t]{3}{*}{ (I) } & Maximal eigenvalue statistics & & & & \\
\hline & $\mathrm{r}=0$ & $\mathrm{r}=1$ & 44.304 & 30.083 & 26.943 \\
\hline & $\mathrm{r}<=1$ & $\mathrm{r}=2$ & 10.672 & 22.240 & 19.704 \\
\hline \multirow[t]{4}{*}{ (II) } & Trace statistics & & & & \\
\hline & $\mathrm{r}=0$ & $\mathrm{r}=1$ & 60.480 & 48.523 & 44.665 \\
\hline & $\mathrm{r}=1$ & $\mathrm{r}=2$ & 16.177 & 29.354 & 25.806 \\
\hline & $\mathrm{H} 0$ & H1 & Test statistics & $5 \% \mathrm{cv}$ & $\begin{array}{c}10 \% \\
\mathrm{cv}\end{array}$ \\
\hline \multicolumn{6}{|c|}{ Model III } \\
\hline \multirow[t]{3}{*}{ (I) } & Maximal eigenvalue statistics & & & & \\
\hline & $\mathrm{r}=0$ & $\mathrm{r}=1$ & 44.891 & 32.165 & 29.645 \\
\hline & $\mathrm{r}<=1$ & $\mathrm{r}=2$ & 20.870 & 25.557 & 23.217 \\
\hline \multirow[t]{3}{*}{ (II) } & Trace statistics & & & & \\
\hline & $\mathrm{r}=0$ & $\mathrm{r}=1$ & 77.591 & 59.829 & 55.752 \\
\hline & $\mathrm{r}=1$ & $\mathrm{r}=2$ & 32.701 & 38.353 & 35.476 \\
\hline
\end{tabular}

Source: Author.

The results obtained are reported in Tables 7, 8 and 9 and the corresponding mean responses are shown in Figures 4, 5 and 6 . Estimations show that the aggregate financial crises (Model I) have a highly significant positive association with the informal economy (see Table 7 and Figure 4). Financial crises build up substantial positive responses from year 0 year 4 but do not add much to the positive effects on the informal economy, especially after year 6 and subsequent years after crises. However, the effect of financial crises on the informal economy is very strong (in size and in statistical significance).

Turning now to the comparison of effects from a financial crisis for a baseline model and an alternative model, the results show that a financial crisis produces slightly larger responses within the informal economy using the alternative measurements. The cumulative positive response is about $82.9 \%$ for the alternative model, which is greater than the cumulative response for the baseline model at $73 \%$. In addition, the immediate effect of financial crises is significant in the year of the crises. However, both the baseline model and the alternative model of a 
financial crisis show that the effect remains positive and significant in year 1 and thereafter for 10 years.

Table 7. Mean Response of the Informal Economy to Financial Crises (Alternative Model)

\begin{tabular}{|l|c|}
\hline Years & Financial crises \\
\hline Year 0 (instantaneous response) & $0.023^{* * * *}$ \\
\hline Year 1 & $0.052^{* * * *}$ \\
\hline Year 2 & $0.068^{* * *}$ \\
\hline Year 3 & $0.077^{* * *}$ \\
\hline Year 4 & $0.082^{* * *}$ \\
\hline Year 5 & $0.085^{* * * *}$ \\
\hline Year 6 & $0.087^{* * * *}$ \\
\hline Year 7 & $0.088^{* * *}$ \\
\hline Year 8 & $0.089^{* * * *}$ \\
\hline Year 9 & $0.089^{* * *}$ \\
\hline Year 10 & $0.089^{* * * *}$ \\
\hline
\end{tabular}

Source: Author.

Notes: (a) ${ }^{* * *}$ indicate $1 \%$ significance level respectively; (b) 1000 replications were used in bootstrap confidence interval of impulse responses.

Figure 4. Mean Response of the Informal Economy to Financial Crises (Alternative Model)

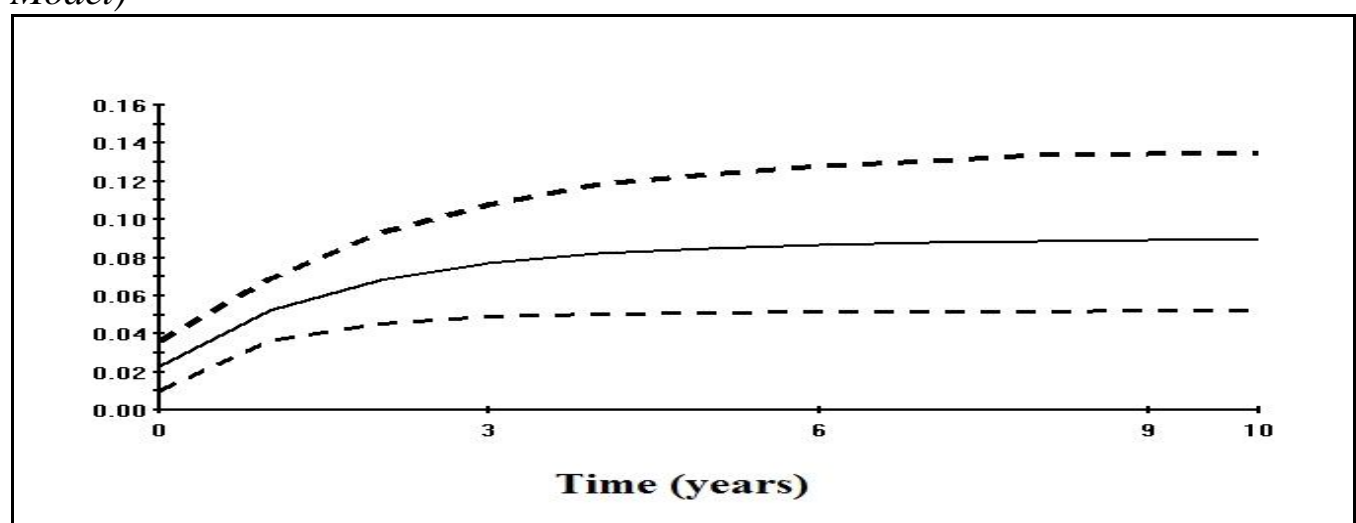

Source: Author.

Note: the solid line represents the estimated IRF and dotted lines represent $95 \%$ confidence interval.

With regard to internal and external crises, the mean responses are summarised in Table 8 and ensuing impulse response functions are portrayed in Figure 5. The results show that internal crises have an overall positive and significant effect on the informal economy (see Table 8, column (a) and Figure 5, graph (a)). More specifically, the mean response of the informal economy to internal crises is significantly positive at the $2.9 \%$ level in year 0 , the effect stays highly significant in the following years and there is no sign of a decrease in positive responses over a 10-year period. This suggests that the effects of internal 
crises on the informal economy are permanent. Compared with the baseline model of an internal crisis, the mean response of the informal economy to an internal crisis was found to be significantly more positive using the alternative model for internal crises. This implies that the mean responses of the informal economy are larger in size using the alternative model of internal crises. Regarding the cumulative mean responses to an internal crisis of the alternative model, this amounted to $79.8 \%$, which is substantially higher than that for the informal economy using the baseline model for an internal crisis (54.4\%).

Table 8. Mean Response of the Informal Economy to Internal and External Crises (Alternative Model)

\begin{tabular}{|l|c|c|}
\hline Years & Internal crises (a) & External crises (b) \\
\hline Year 0 (instantaneous response) & $0.029^{* * * *}$ & 0.003 \\
\hline Year 1 & $0.052^{* * * *}$ & $0.022^{* *}$ \\
\hline Year 2 & $0.064^{* * * *}$ & $0.030^{* * * *}$ \\
\hline Year 3 & $0.072^{* * *}$ & $0.036^{* * *}$ \\
\hline Year 4 & $0.077^{* * * *}$ & $0.039^{* * *}$ \\
\hline Year 5 & $0.080^{* * * *}$ & $0.042^{\text {**** }}$ \\
\hline Year 6 & $0.083^{* * * *}$ & $0.043^{* * *}$ \\
\hline Year 7 & $0.084^{* * * *}$ & $0.044^{* * *}$ \\
\hline Year 8 & $0.085^{* * * *}$ & $0.045^{* * *}$ \\
\hline Year 9 & $0.086^{* * * *}$ & $0.045^{* * *}$ \\
\hline Year 10 & $0.086^{* * * *}$ & $0.046^{* * *}$ \\
\hline
\end{tabular}

Source: Author.

Notes: (a) ${ }^{* * *}$ and ${ }^{* * *}$ indicate $5 \%$ and $1 \%$ significance level of financial crisis shocks respectively; (b) 1000 replications were used in the bootstrap confidence interval of impulse responses.

On the other hand, regarding the impact of an external crisis, as shown in Table 8, column (b) and Figure 5, graph (b), the positive effect is not statistically significant in year 0 , but builds up to become statistically significant in terms of positive effects in year 1 and subsequent years. It seems that time is a crucial factor in the expansion of the effects of external crises on other countries. It should be noted that the results for the mean responses for the informal economy using the alternative model of an external crisis are weaker in terms of size than in the case of the baseline model. However, both baseline and alternative models of external crises indicate that there is no sign of a drop in the responses of the informal economy over a long-term horizon, indicating the persistent effects of external crises. 
Figure 5. Mean Response of the Informal Economy to Internal and External Crises (Alternative Model)

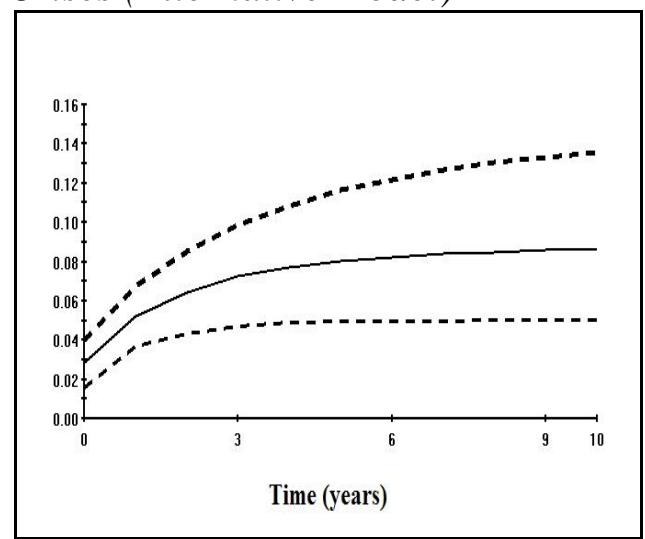

(a)

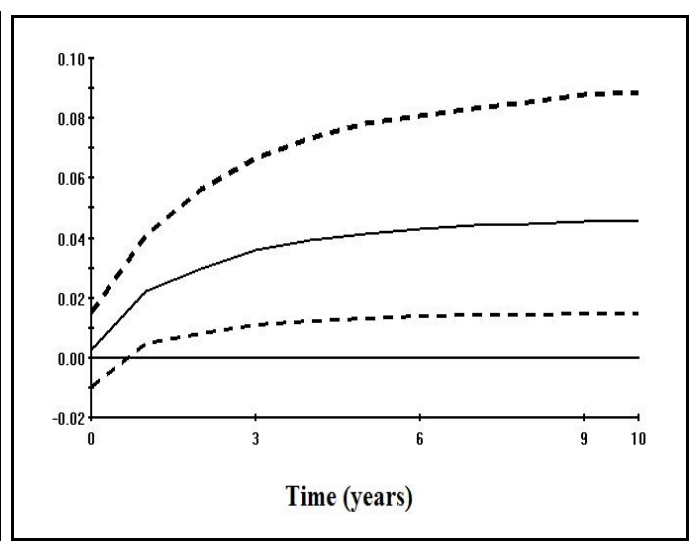

(b)

Source: Author.

Note: the solid line represents the estimated IRF and dotted lines represent $95 \%$ confidence interval.

Comparing an internal vs. external crisis using the alternative model, as can be seen from Table 8 in the year of the crisis, the mean response of the informal economy is significantly more positive than the response to an external crisis. In fact, in year 0 , an external crisis has no significant impact on the informal economy. In contrast to this, the effects of an internal crisis are more severe. For example, in year 1 , an internal crisis would have had more than two times the impact on the informal economy than an external crisis. In the following years, an internal crisis would have almost twice the positive impact on the informal economy than external crises.

Focusing on currency and banking crises, the estimated mean responses of the informal economy are presented in Table 9 and Figure 6. Currency crises, as shown in Table 9 column (a) and Figure 6, graph (a), tend to have a positive effect on the informal economy, but the effects are not statistically significant. The response of the informal economy is significantly positive in year 1 and remains positive and significant thereafter. Although mean responses remain consistently positive and significant in the following years, the positive effects of such 'twin' crises do not fluctuate and do not build over time into substantial amounts. Using an alternative model of the currency crisis, the results show that these produce larger and induce stronger responses within the informal economy than the baseline model shows for currency crises. The cumulative effect of a currency crisis for the alternative model is about $63.9 \%$, which is significantly higher than the cumulative effects of such crises on the baseline model (35.5\%). 
Table 9. Mean Response of the Informal Economy to Currency and Banking Crises (Alternative Model)

\begin{tabular}{|l|c|c|}
\hline Years & Currency crises (a) & Banking crises (b) \\
\hline Year 0 (instantaneous response) & 0.007 & $0.016^{* *}$ \\
\hline Year 1 & $0.039^{* * *}$ & $0.026^{* *}$ \\
\hline Year 2 & $0.054^{* * *}$ & $0.030^{* *}$ \\
\hline Year 3 & $0.061^{* * *}$ & $0.032^{* *}$ \\
\hline Year 4 & $0.065^{* * *}$ & $0.034^{* *}$ \\
\hline Year 5 & $0.067^{* * *}$ & $0.034^{* *}$ \\
\hline Year 6 & $0.068^{* * *}$ & $0.035^{* *}$ \\
\hline Year 7 & $0.069^{* * *}$ & $0.035^{* *}$ \\
\hline Year 8 & $0.069^{* * *}$ & $0.035^{* *}$ \\
\hline Year 9 & $0.070^{* * *}$ & $0.035^{* *}$ \\
\hline Year 10 & $0.070^{* * *}$ & $0.035^{* *}$ \\
\hline
\end{tabular}

Source: Author.

Notes: (a) ${ }^{* *}$ and ${ }^{* * *}$ indicate $5 \%$ and $1 \%$ significance level of financial crisis shocks respectively (b) 1000 replications were used in the bootstrap confidence interval of impulse responses.

Figure 6. Mean Response of the Informal Economy to Currency and Banking Crises (Alternative Model)

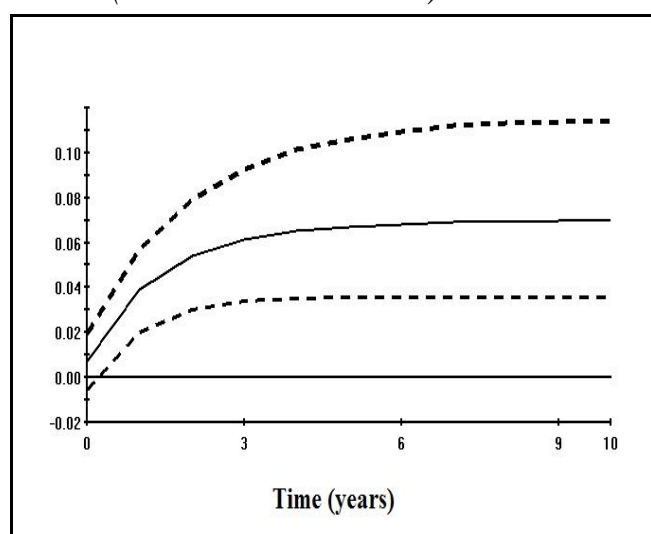

(a)

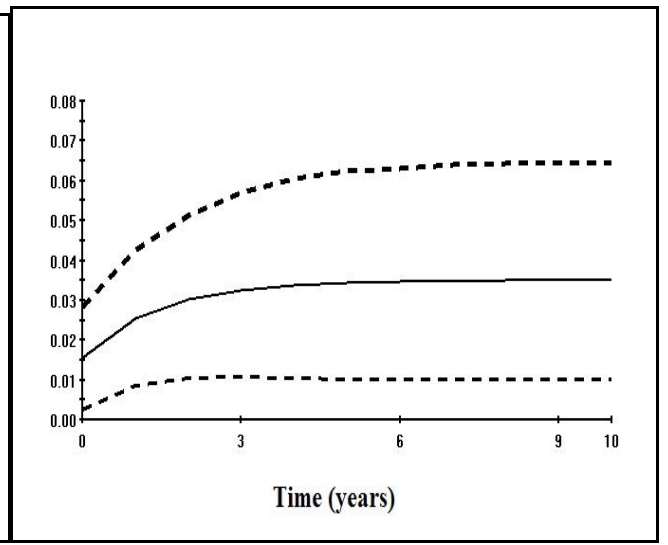

(b)

Source: Author.

Note: the solid line represents the estimated IRF and dotted lines represent $95 \%$ confidence interval.

A banking crisis seems to have a significant positive impact on the informal economy in the year of the crisis and in subsequent years. Specifically, in year 0, a banking crisis has more than twice the positive impact on the informal economy than a currency crisis. Although the immediate effect of a banking crisis is significantly more positive than for a currency crisis, the effect becomes weaker in size and statistical significance in year 1 and in the following years. Furthermore, the results show that the mean responses of the informal economy are not only weaker to banking crises in terms of size they are even weaker in terms of statistical significance using the alternative model of banking crises than a baseline 
model of banking crises. Thus, the cumulative impacts of a banking crisis are more positive using the baseline model $(49.8 \%)$ than using the alternative model (34.7\%). The cumulative effects in both cases, nonetheless, remain significantly positive. Overall, the effects of currency and banking crises are positive on the informal economy and in general are in line with our previous results.

\section{Conclusion}

This paper attempted to analyse the path of the informal economy in times of crises. To do so, three VARX models for Turkey were estimated for the period 1980-2011. The first model was used to measure the aggregate impacts of financial crises on the informal economy. The second model explored the separate effects of internal and external financial crises, and the latter examined the effects of banking versus currency crises on the informal economy.

Most of the studies in the literature tend to investigate the impact of the financial crises on the official economy, without considering differences across the official and the informal economy. Too little attention - only a few empirical studies (e.g. Colombo at al. 2012, Colombo et al. 2016) has been paid to examining the impact of the financial crises directly on the informal economy across the world. Roco et al. (2001) and Elgin (2012) highlight the role of the informal economy as countercyclical in times of crises. Looking specifically at Turkey, there are no empirical studies exploring the impact of financial crises on the informal economy. On these grounds, the present paper fills this gap and contribute to the literature by providing an empirical investigation on the impact of financial crises on the informal economy in Turkey. Turkey is a particularly interesting case to investigate the relationship between the informal economy and financial crises, not least because it has a large informal economy, and since the 1980s has seen widespread economic, political and institutional changes. Financial liberalisation had been expected to achieve stability, inspire business confidence to invest and produce stable growth with controlled inflation. However, having experienced a series of crises, Turkey has suffered from chronic unemployment problems, which again reinforces the importance of the informal economy - as it is to this that the unemployed turn, sometimes merely to live, but also to add to a limited income by those working within the state system and thus largely in the formal economy.

The goal has been to verify the reliability of our results by exploring the effect of distinct types of crises on the informal economy. We provide evidence that each type of financial crises is positively associated with the informal economy and that the effect of each crisis was permanent, commonly lasting 10 years in Turkey. In an attempt to find the impact of distinct types of financial crises, the effect of aggregate financial crises is felt one year after the crises and the effect remains highly significant in subsequent years. With regard to internal crises versus external crises, the immediate effect of internal crises is positive and significant, unlike external crises where the positive and significant effect occurs with some delay. This implies that external crises take time, propagating in other countries 
through various transmission channels. Having considered the effects of currency and banking crises, they both have an overall positive impact on the informal economy. Therefore, our results are in line with the literature (Colombo et al. 2012, 2016), suggesting that the informal economy tends to act as a powerful buffer in times of financial crisis. The present findings also suggest a negative inter-connection between the informal economy and the real GDP.

The Turkish government must attune their understanding of the role of the informal economy as the main job provider for unemployed people, crucial for economic development and reducing unemployment and poverty. At the same time, key policy objectives from the perspective of development need to be considered in order to improve the employment opportunities, income, social security, quality of informal work and the outcome of individuals in the informal economy. This will contribute to social and individual welfare and encourage microfinance institutions, thus contributing to economic development. While efforts should be made to address negative aspects of the informal economy and support people in the informal economy, it is important not to destroy its capacity to provide livelihoods and to develop output, employment and entrepreneurial potential. The potential of the informal economy cannot be overlooked in Turkey. In this case, Turkish-policy makers should consider equal opportunities for both informal and formal workers. Informal workers are often poor, less educated and low skilled individuals, and vocational training and education programs will improve their professional knowledge and skills. Additionally, Turkey requires policies to improve attitude towards informal workers. Finally, considering that the informal economy and unemployment are facts of the Turkish economy and these activities may be undertaken by terrorist organisations, and can finance terrorist attacks, Turkey might consider the legalise the informal economy.

Although this paper is the first empirical study exploring the impact of financial crises on the informal economy in the Turkish context it would be interesting to assess the effects of financial crises on the informal economy in other countries and compare. A further study could also assess the effects of financial crises using a high frequency of data i.e. quarterly data to analyse the very immediate effects of crises.

\section{References}

Aras NO (2010) Effects of the global financial crisis on the Turkish banking sector. International Journal of Economics and Finance Studies 2(1): 113-120.

Babecky J, Havranek T, Mateju J, Rusnak M, Smidkova K, Vasicek B (2012) Banking, debt, and currency crises: Early warning indicators for developed countries European Central Bank. Working Paper No.1485.

Barro R (2001) Economic growth in East Asia before and after the financial crisis. NBER Working Paper No. 8330.

Buehn A, Schneider F (2012) Shadow economies around the world: Novel insights, accepted knowledge, and new estimates. International Tax and Public Finance 19(1): 139-171. 
Cerra V, Saxena C (2008) Growth dynamics: The myth of economic recovery. American Economic Review 98(1): 439-467

Choudhry TM, Marelli E, Signorelli M (2012) Youth Unemployment Rate and Impact of Financial Crises. International Journal of Manpower 3(1):76-95.

Colombo E, Onnis L, Tirelli P (2012) The shadow size of financial crises. Work in progress.

Colombo E, Onnis L, Tirelli P (2016) Shadow economies at times of banking crises: Empirics and theory. Journal of Banking and Finance 62(1): 34-51.

Dell'Ariccia G, Detragiache E, Rajan R (2008) The Real Effect of Banking Crises. Journal of Financial Intermediation 17: 89-112.

Demirguc-Kunt A, Detragiache E, Gupta P (2000) Inside the crisis: An empirical analysis of the banking system in distress. IMF Working Paper No.156.

Elgin C (2012) Cyclicality of the informal economy. Bogazici University Department of Economics Working Paper No.2012/02.

Ercan H (2011) Occupational Outlook in Turkey. Ankara: ILO Office for Turkey.

Eurofound (2013) Tackling undeclared work in Turkey. Dublin: European Foundation for the Improvement of Living and Working Conditions (Eurofound).

Fomby T, Ikeda Y, Loayza N (2013) The growth aftermath of natural disasters. Journal of Applied Econometrics 28(3):412-434.

Fukuda T (2012) Financial development, economic growth and financial crisis in Asian emerging economies. Research in Applied Economics 4(2): 1-22.

Furceri P, Zdzienicka A (2011) The real effect of financial crises in the European transition economies. Economics of Transition 19(1): 1-25.

Gupta P, Mishra D, Sahay R (2007) Behaviour of output during currency crises. Journal of International Economics 72(2): 428-450.

Hutchison M, Noy I (2002) Output cost of currency and balance of payment crises in emerging markets. Comparative Economic Studies XLIV(2): 27-44.

Hutchison M, Noy I (2005) How bad are twins? The output cost of currency and banking crises. Journal of Money, Credit and Banking 37(4): 725-752.

ILO (2012) The youth unemployment crises: Time for action. Geneva. Available at: http:// adapt.it/adapt-indice-a-z/wp-content/uploads/2013/08/ILO_The-youth-employmentcrisis.pdf.

Johansen S (1988) Statistical analysis of cointegrating vectors. Journal of Economic Dynamics and Control 12(2-3): 231-254.

Johansen S (1991) Estimation and hypothesis testing of cointegration vectors in Gaussian vector autoregressive models. Econometrica 59(6):1551-1580.

Knotek SE, Terry S (2009) How will unemployment fare following the recession. Economic Review 93(3): 5-33.

Kroeger A, Meier K (2011) Labour markets and the financial crisis: Evidence from Tajikistan. DIW Discussion Paper No.1174.

Laeven L, Valencia (2010) Resolution of banking crises: The good, the bad and the ugly. IMF Working Paper No.146.

Lee K, Pesaran MH (1999) Econometric analysis of non-linear dynamic models with application in international macroeconomics. ESRC end of Award Report.

Nathanson R, Brand G (2011) Economic overview of Turkey. The Macro Centre for Political Economics. Israeli European Policy Network IEPN.

Oulton N, Barriel SM. (2013) Long and short-term effects of the financial crisis on labour productivity, capital and output. Bank of England Working Paper No.470.

Ozturk M, Aras NO (2011) Foreign capital investments and economic crisis in Turkey. International Journal of Social Sciences and Humanity Studies 3(1): 323-335. 
Pesaran MH, Shin Y, Smith RJ (1997) Structural analysis of vector autoregressive models with exogenous I(1) variables. DAE Working Paper No.9706.

Pesaran MH, Shin Y (1998) Generalised impulse response analysis in multivariate models. Economic Letters 58(1): 17-29.

Pesaran MH, Shin Y, Smith RJ (2000) Structural analysis of vector error correction models with exogenous I(1) variables. Journal of Econometrics 97(2): 293-343.

Pesaran B, Pesaran MH (2009) Time-Series Econometrics using Microfit 5.0. UK: Oxford University Press.

Qerimi RQ, Sergi BS (2017) The nature and the scope of the global crisis' impact on employment trends and policies in South East Europe. Journal of International Studies 10(4): 1-14.

Reinhart C, Rogoff K (2009) This time is different: Eight centuries of financial follyChapter1. The MPRA Working Paper No.17452.

Reinhart C (2010) This time is different chartbook: Country Histories on debt, default and financial crises. NBER Working Paper No.15815.

Reinhart C, Rogoff K (2011) From financial crash to debt crises. American Economic Review 101(5): 1676-1706.

Reinhart C, Rogoff K (2009) This time is different eight centuries of financial folly. Princeton University Press. Retrieved from http://www.reinhartandrogoff.com/

Roca, CCJ, Moreno DC, Sanches GEJ (2001) Underground economy and aggregate fluctuations. Spanish Economic Review 3(1): 41-53.

Schneider F, Buehn A, Montenegro EC (2010) Shadow economies all over the world: New estimates for 162 countries from 1999 to 2007. World Bank Policy Research Working Paper No. 5356.

Schneider F, Buehn A (2012) Shadow economies in highly developed OECD countries: What are the driving forces? IZA Discussion Paper No.6891.

Simsek M (2014) Economic Shadows and Light. Available at: https://www.projectsyndicate.org.

Temiz D, Gokmen A (2009) The 2000-2001 financial crises in Turkey and the global economic crisis of 2008-2009: Reasons and comparisons. International Journal of Social Sciences and Humanity Studies 1(1): 1-16.

Verdugo EL, Furceri D, Guillaume D (2012) Crises, labour market policy, and unemployment. IMF Working Paper No.65.

Yazir S (2010) Adverse impact of the global financial crisis on employment and social security in Turkey. Council of Europe SSC SSR Report.

Yendi L, Cetin S, Gallo A (2012) The Turkish economy and the global crisis. International Business: Research Teaching and Practice 6(2):45-58.

World Bank (2010) Turkey country economic memorandum: Informality: Causes, consequences and policies. The World Bank Report No. 48523. 


\section{Appendix}

Table A1. Definition of Financial Crises by Reinhart and Rogoff

\begin{tabular}{|l|l|}
\hline Currency Crises & $\begin{array}{l}\text { Defined as annual depreciation of currency versus relevant } \\
\text { anchor currency of 15 or more }\end{array}$ \\
\hline Banking Crises & $\begin{array}{l}\text { Defined as (I) bank runs that lead to closure, merging or } \\
\text { takeover given by the public sector of one or more financial } \\
\text { institutions. (II)if there are no bank runs, the closure merging } \\
\text { and takeover or large scale of government assistance of } \\
\text { important financial institutions that mark the start of a string } \\
\text { of similar institutions. }\end{array}$ \\
\hline External debt crises & $\begin{array}{l}\text { The failure of the government to meet a principal or interest } \\
\text { payments on the due date under the jurisdiction of foreign } \\
\text { law }\end{array}$ \\
\hline Domestic debt crises & $\begin{array}{l}\text { The same definition applied above applied to domestic debt } \\
\text { crises under the country's own law }\end{array}$ \\
\hline
\end{tabular}

Figure A1. Mean Response of GDP

Response to financial crises (a)

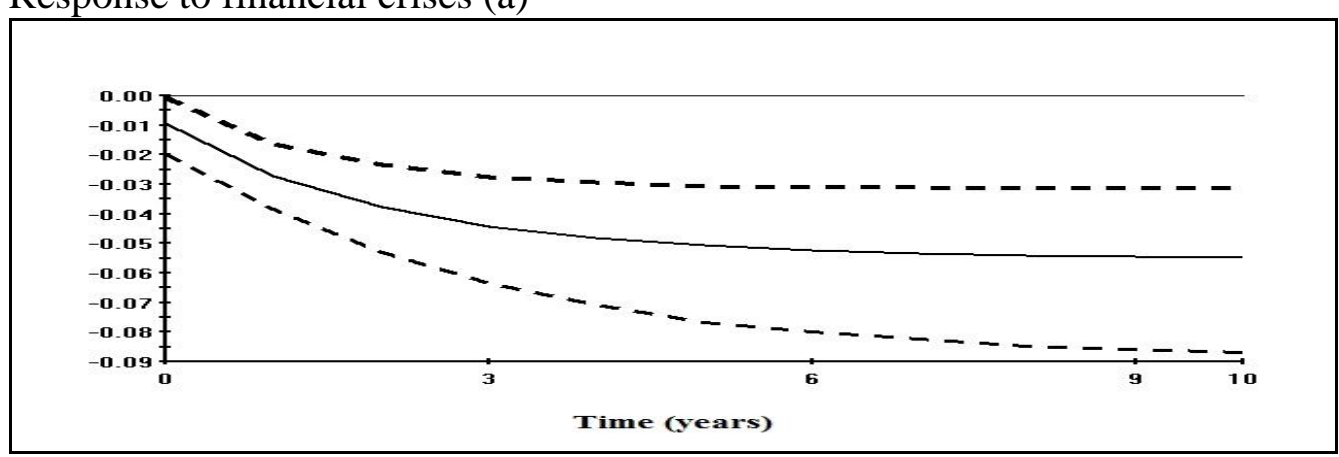

Response to internal crises (b)

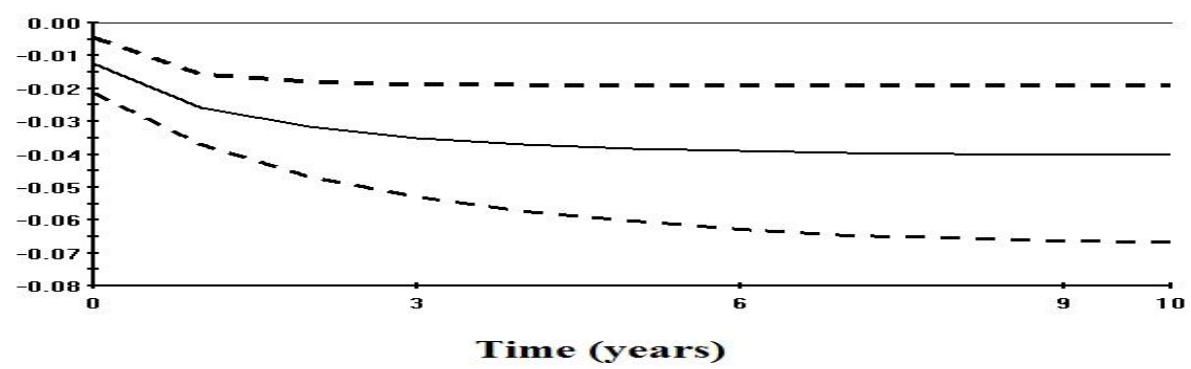


Response to external crises (c)

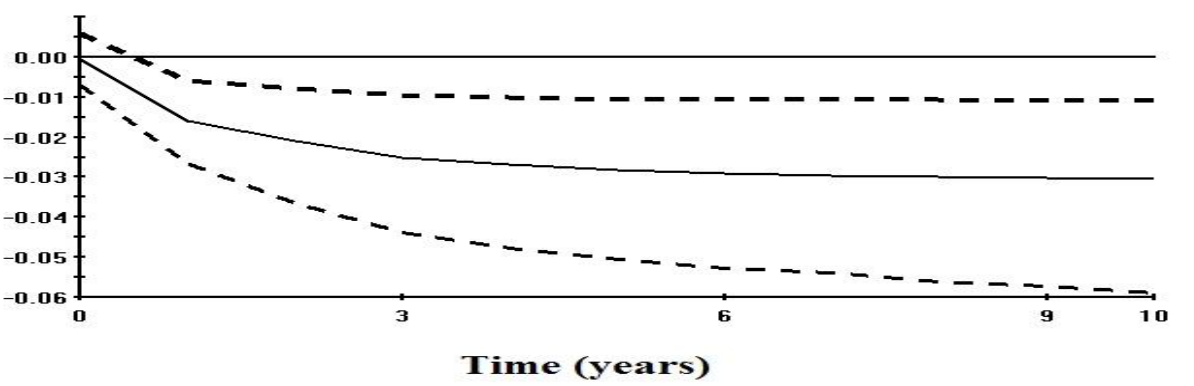

Response to currency crises (d)

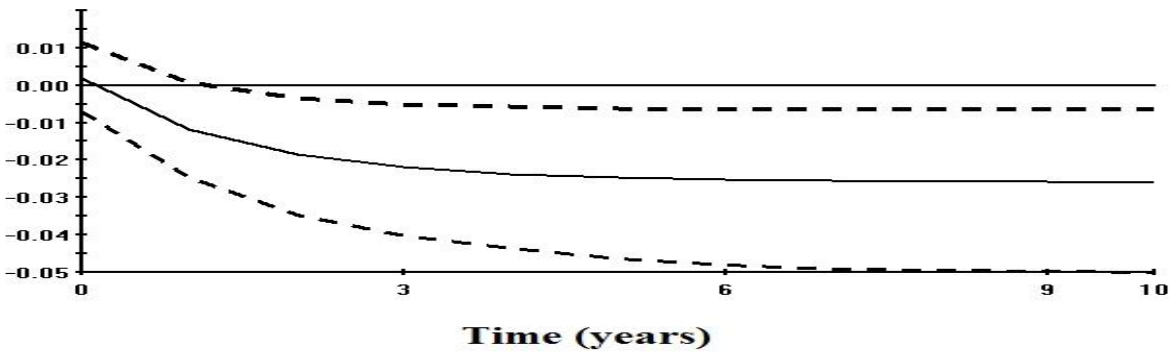

Response to banking crises (e)

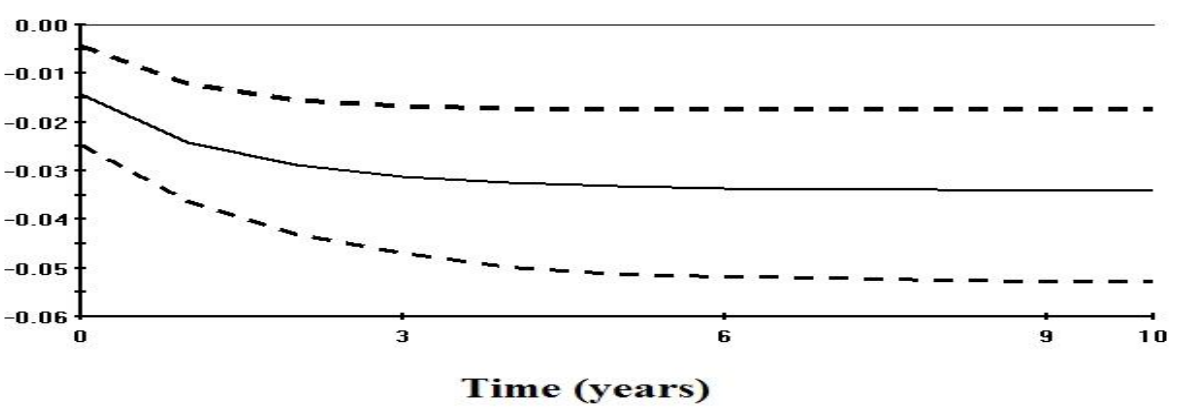


Figure A2. Mean Response of GDP (Alternative Models of a Financial Crisis) The response of GDP to financial crises (f)

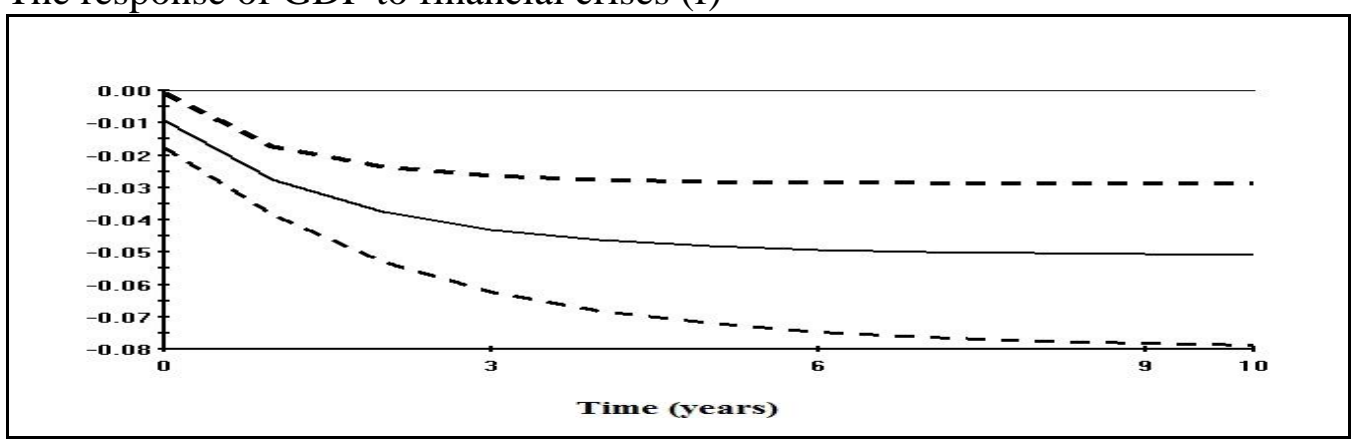

The response of GDP to internal crises $(\mathrm{g})$

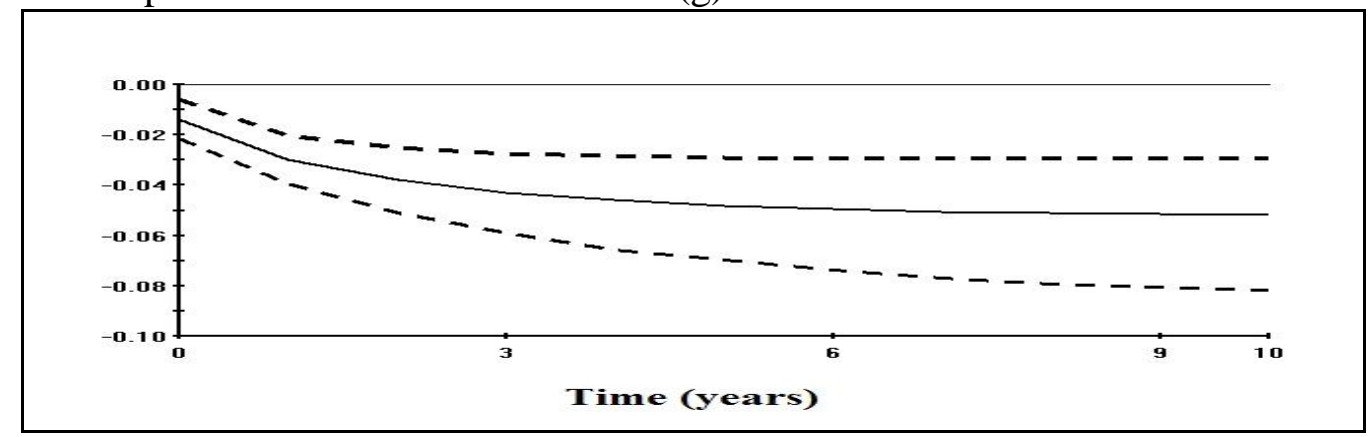

The response of GDP to external crises (h)

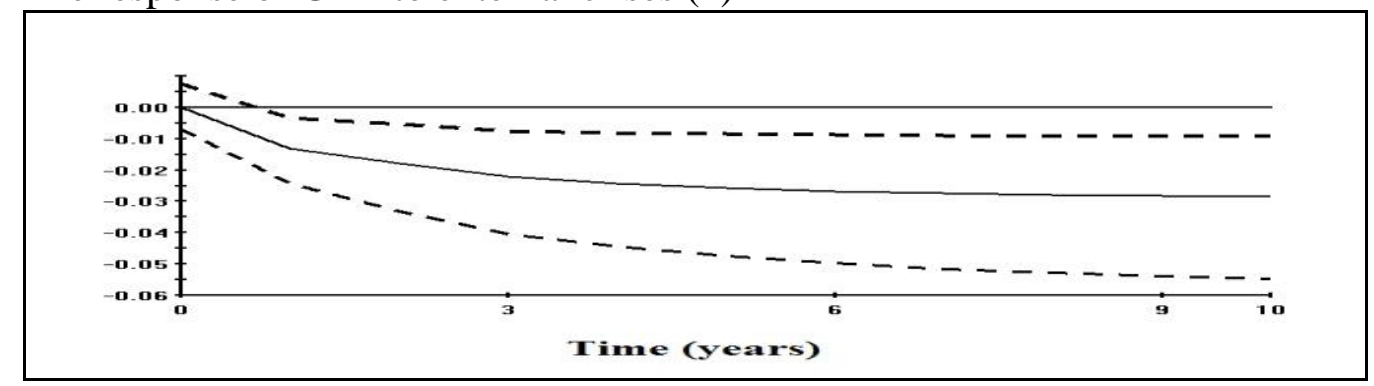

The response of GDP to currency crises (i)

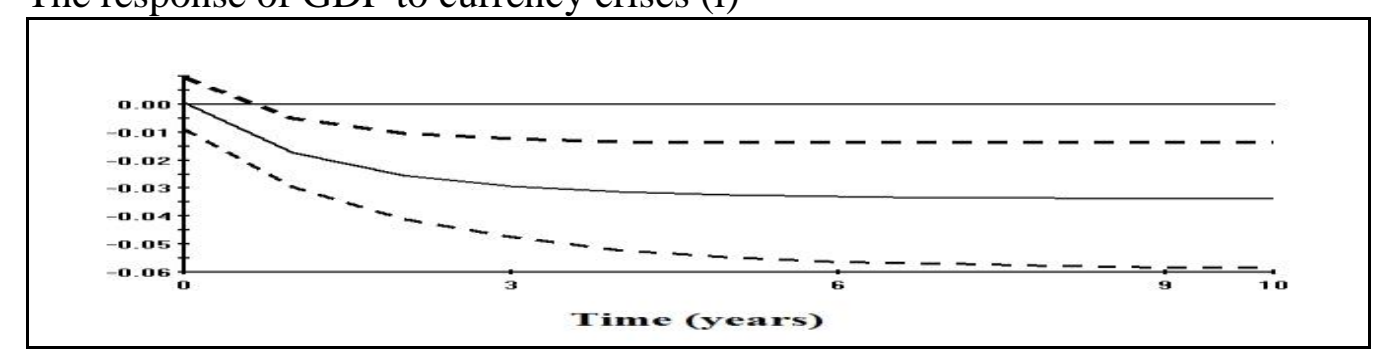

The response of GDP to banking crises (j)

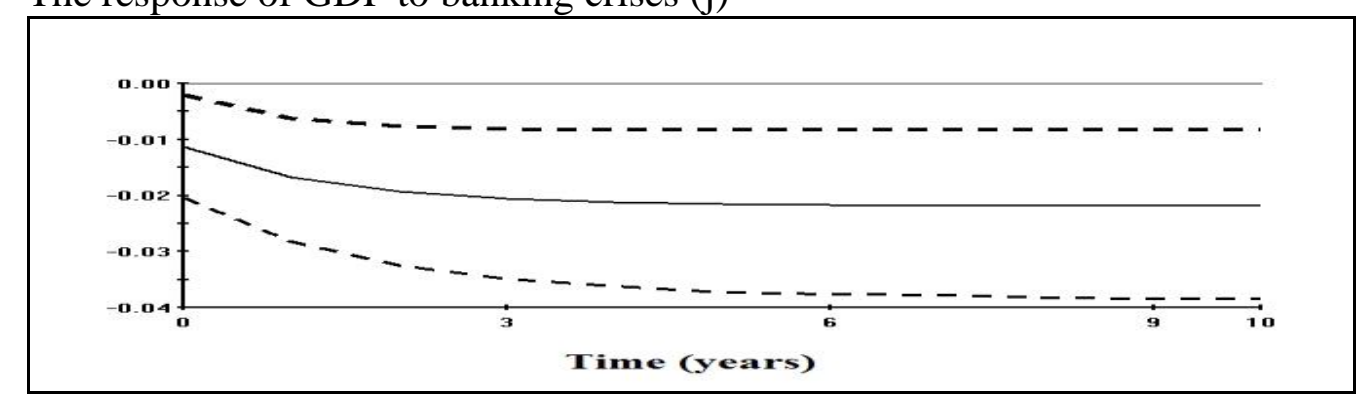

